\title{
Integration of hydrogeophysical and geological investigations in enhancing groundwater potential assessment in Houtriver gneiss crystalline basement formation of South Africa
}

\author{
Innocent Muchingami ${ }^{\text {a, e,f, }}$, Andrew Mkali ${ }^{a}$, Lusanda Vinqi ${ }^{a}$, Kevin Pietersen ${ }^{a}$, Yongxin Xu ${ }^{a}$, \\ Robert Whitehead $^{\mathrm{d}}$, Jansen Karsten ${ }^{\mathrm{b}}$, Karen Villholth ${ }^{\mathrm{c}}$, Thokozani Kanyerere ${ }^{\mathrm{a}}$ \\ ${ }^{a}$ UNESCO Chair Centre in Groundwater, University of the Western Cape, South Africa \\ ${ }^{\mathrm{b}}$ Centre of Hydrology University of Copen Hagen, Denmark \\ ${ }^{\mathrm{c}}$ International Water Management Institute, Pretoria, South Africa \\ ${ }^{\mathrm{d}}$ Department of Water Affairs, Limpopo Water Management Area, Polokwane, South Africa \\ e Geophysics Research Group, National University of Science and Technology, Zimbabwe \\ ${ }^{\mathrm{f}}$ Geology Department, University of Namibia, Namibia
}

\section{A R T I C L E I N F O}

\section{Keywords:}

Crystalline basement

Houtriver gneiss

Hydrogeophysics

Groundwater potential

\begin{abstract}
A B S T R A C T
Groundwater exploration in crystalline basement aquifers such as the Houtriver gneiss formation in the Limpopo province of South Africa is often described as complex. This is because groundwater availability in such aquifers is largely a consequence of the interaction of several processes related to recharge, underlying geological features and fracture connectivity of the aquifer rock matrix. In this study, an integration of geophysical and geological investigations is applied in inferring potential drill targets within the Houtriver gneiss crystalline basement aquifer system. Results from the magnetic and frequency domain electromagnetic surveys were combined with geological investigations to identify sites where vertical electrical resistivity sounding was applied to infer the thickness and layering of weathered and fractured zones, as well as to identify potential targets where test boreholes were drilled. Constructed geo-resistivity pseudo-sections suggested that groundwater occurrence within this formation is described by a heterogeneous multiple-layered and fractured aquifer system with the main groundwater bearing zones ranging from a depth of $30-72 \mathrm{~m}$ in most cases. Ten potential drill sites were identified from which three test boreholes were drilled and used to validate the results through a lithostratigraphic conceptual model developed from the correlation of the geophysical results with drill logs. The integration of hydro-geophysical and geological methods thus provided a comprehensive approach for resource assessment in the Houtriver gneiss formation.
\end{abstract}

\section{Introduction}

Crystalline basement aquifers form a fundamental component of water supply in sub-Saharan Africa with the notable emphasis being its contribution to agricultural and rural domestic water supply, (e.g. in Adams (2009) and Witthüser et al. (2010), and Robins et al. (2013), Holland 2010). The aquifer set up in the crystalline hard rock and its characteristics have been described by various researchers such as Davis and Turk (1964); Tardy (1971); Eswaran and Bin (1978); Ledger and Rowe (1980); Chilton and Smith-Carington (1984); Acworth (1987); Pickens et al. (1987); Nahon (1991); Wright (1992); Chilton and Foster (1995) and Jolly (1986). These aquifers are usually developed within the weathered overburden and fractured bedrock of crystalline rocks of intrusive and/or metamorphic origin which are mainly of Precambrian age and are, despite more often being described as strategic water supply, classified as low yielding (Wright, 1992). As such, groundwater exploration in such aquifers is often described as a more complex process since groundwater availability in such system is largely a consequence of the interaction of several processes related to recharge, underlying geological features and fracture connectivity of the aquifer rock matrix. In South Africa's Limpopo basin, for instance, has its groundwater resources largely contained within the Hout river gneiss crystalline basement formation (Holland, 2011). Like most basement aquifers, this formation is characterised by high variability in terms of

\footnotetext{
* Corresponding author. UNESCO Chair Centre in Groundwater, University of the Western Cape, South Africa.

E-mail address: innocent.muchingami@nust.ac.zw (I. Muchingami).
} 


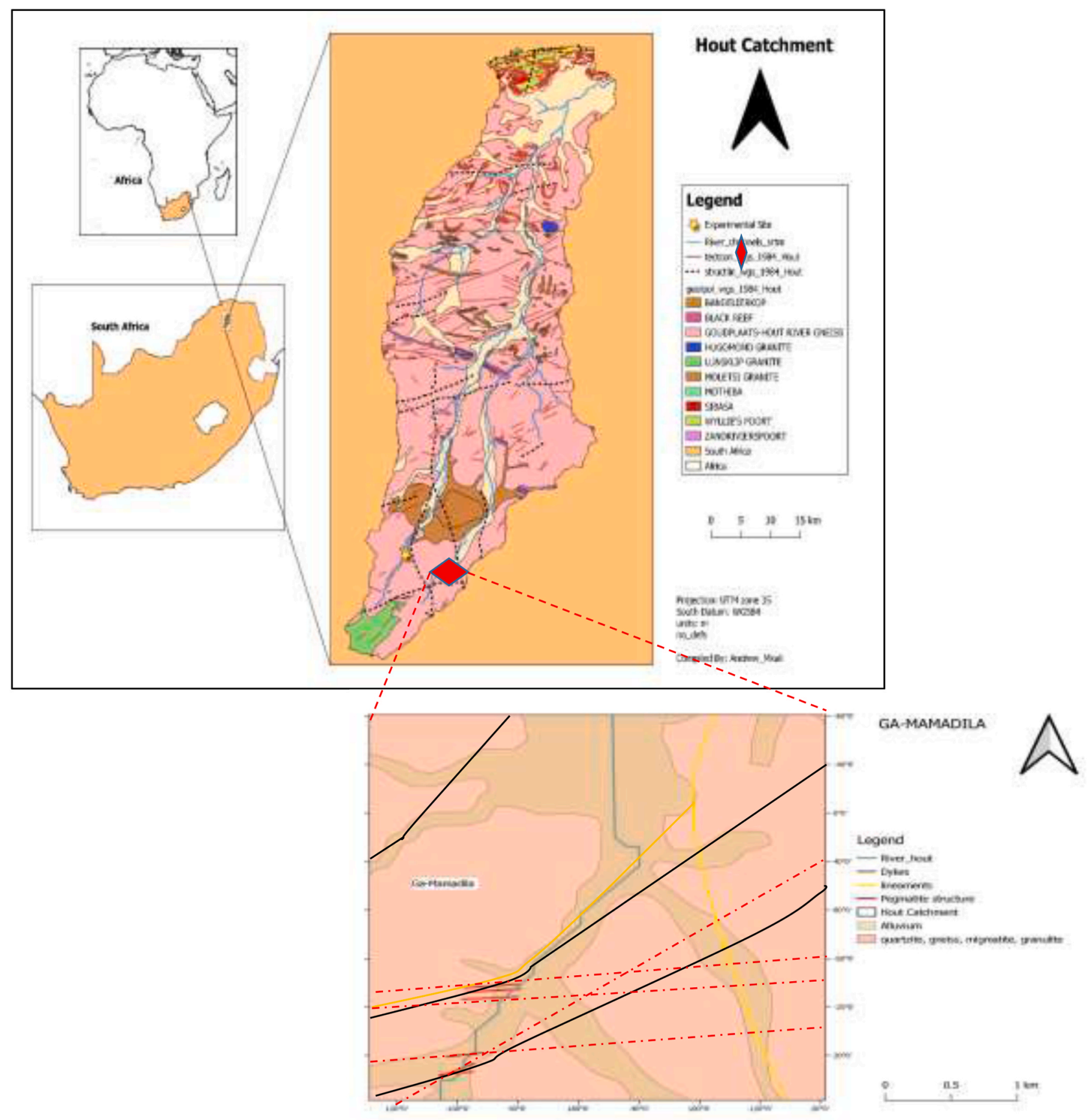

Fig. 1. Locality map of the Ga-Mamadila study site within the Hout river catchment area showing the local geology of the catchment. 


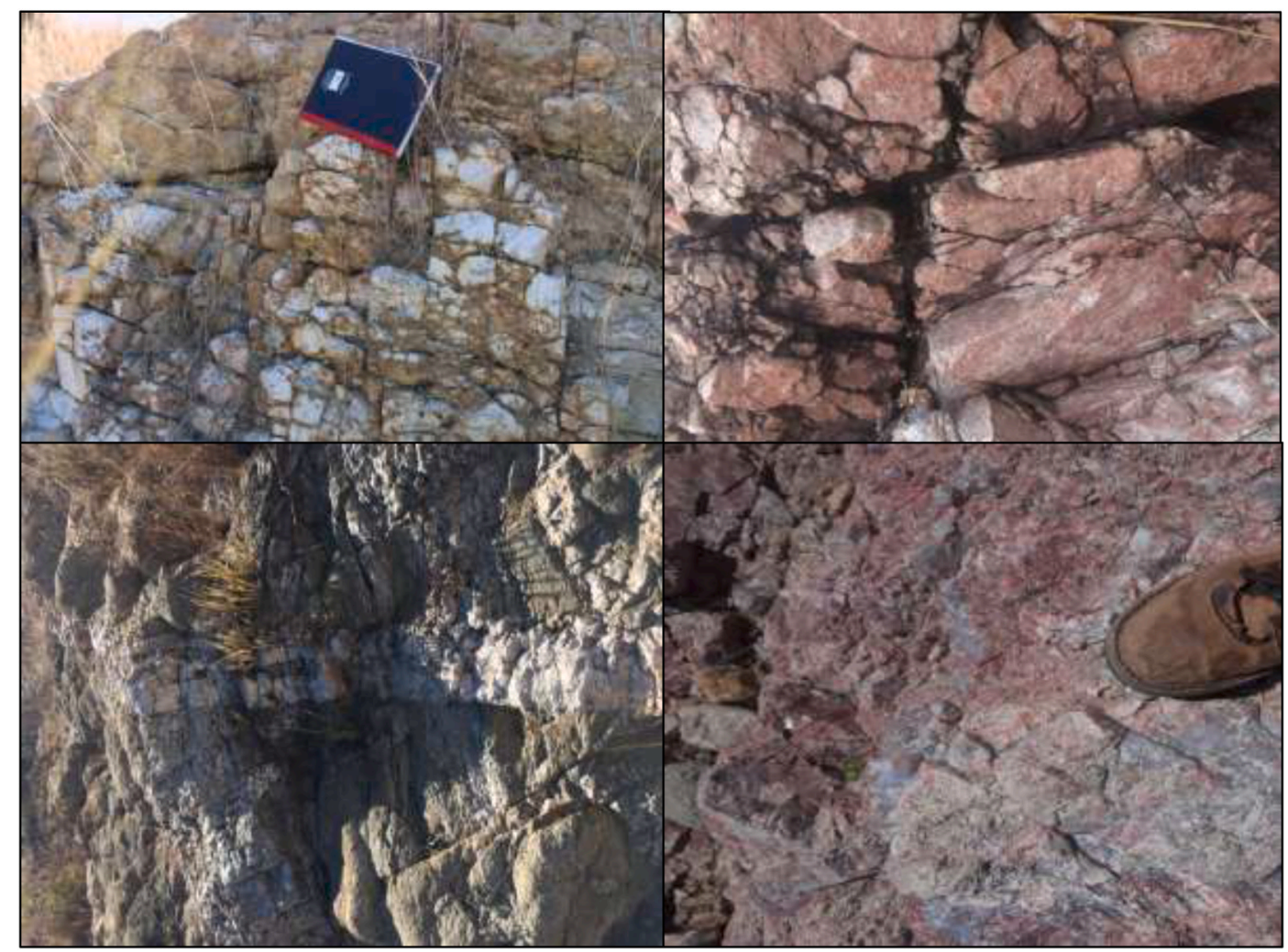

Fig. 2. Photographic image of rock units showing the extent of fracturing and weathering, amongst other structural features within both the grey gneiss and pink pegmatite forming part of the Hout river gneiss formation characterising the study area. The interconnectivity of the fracturing provides evidence that the formation is likely to enhance groundwater movement and availability within the study area. (For interpretation of the references to colour in this figure legend, the reader is referred to the Web version of this article.)

the recharge mechanisms, groundwater resource potential and the approximate depth to which yielding boreholes need to be drilled. Historically, groundwater exploration within such crystalline basement aquifers has been centered on identification of structural features and geological contacts at depth within the rock formation. This is because groundwater movement and storage in this formation has been described by previous researchers to occur via fractures, faults, weathered zones and other secondary features that enhance the aquifer potential only locally with a varying aquifer thickness ranging from depth extending from $12 \mathrm{~m}$ to over $120 \mathrm{~m}$ (Jolly, 1986; du Toit, 2001). The assessment of the groundwater potential and borehole siting in typical crystalline formation aquifers has often presented to be challenging and more often drilling of numerous dry and seasonal boreholes has been reported for poorly sited wells across the formation. This is despite fact that a combination of hydrogeophysical and geological methods has over the years been successfully applied in some crystalline basement aquifers to increase borehole success rates through inferring the subsurface distribution of groundwater controlling structures such as the existence of any geological contacts, dykes and/or lineaments, approximate depth to groundwater table, thickness of the overlying weathered regolith, and the distribution fractured zones within the solid bedrock (e.g. in Zody 1969; Martinelli and Hubert, 1985; Metwaly, 2009, Chandra et al. (2010), Chuma et al., 2013). The current study demonstrates the effectiveness of applying integrated geophysical and geological investigations as appropriate exploration tools for inferring subsurface features useful in identifying potential drill targets in the Houtriver gneiss crystalline basement formation in the Limpopo Province of South Africa.

\section{Study area and geological setting}

The study was conducted in the Mamadila communal area, Polokwane municipality in the Limpopo province of South Africa (Fig. 1). In terms of water management area, the area lies within the Hout river catchment of the Limpopo basin. The Hout catchment has an area of $2478 \mathrm{~km}^{2}$ with an elevation ranging from 840 to $1739 \mathrm{~m}$ above mean sea level (mamsl), and an ephemeral river that flows intermittently following large and intense precipitation events into the Sand River. The catchment is characterised by a semi-arid climate that has an annual precipitation of $300-580 \mathrm{~mm} /$ annum.

\subsection{Hydrogeology of the study area}

Groundwater occurrence within the study area is mainly contained within the Hout river gneiss, a typical crystalline basement metamorphic formation (Jody 1986; Holland 2011). This parent rock formation controlling groundwater occurrence is often exposed as coarse-grained, pinkish grey and pink leucocratic gneiss composed of 


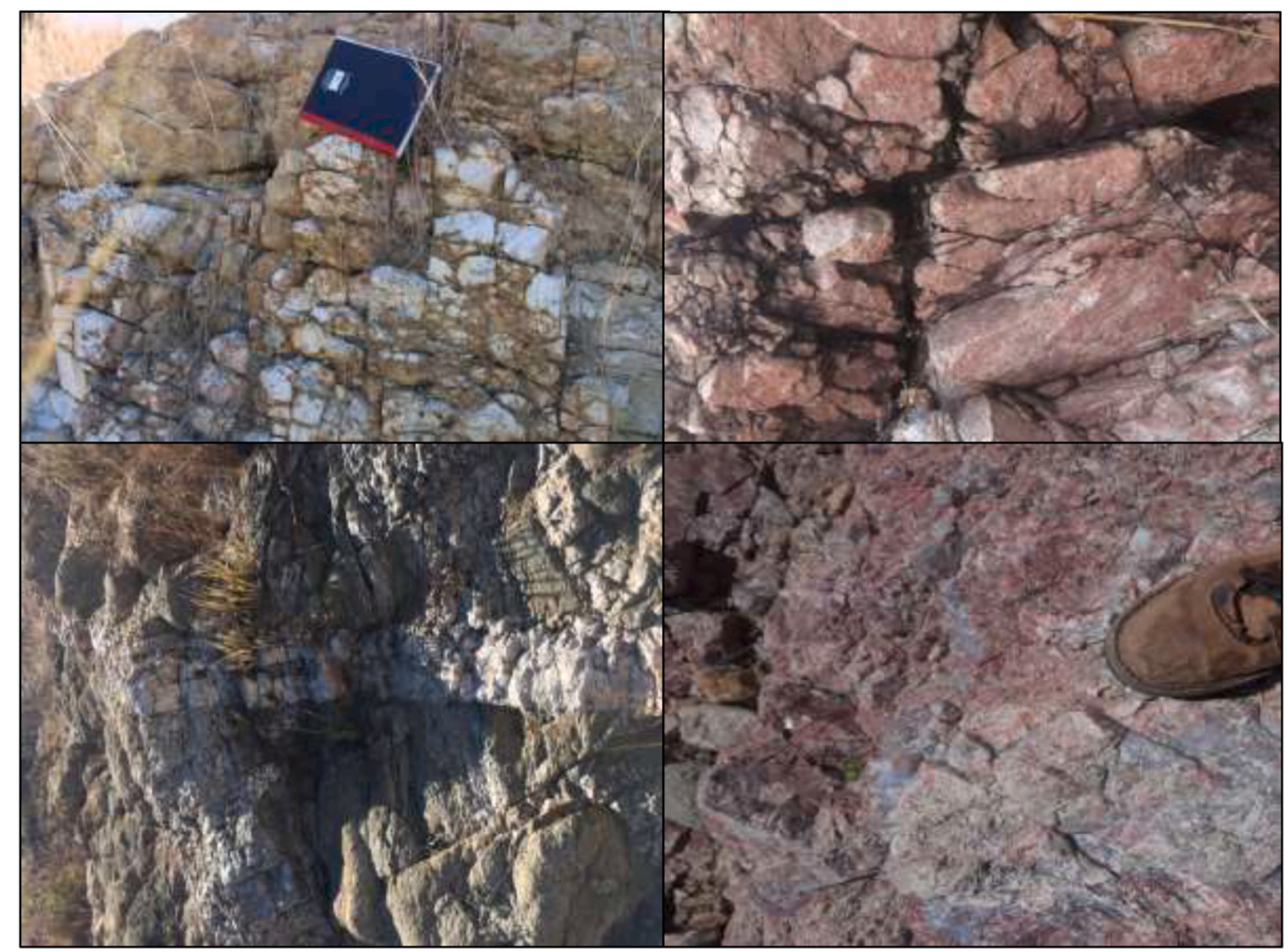

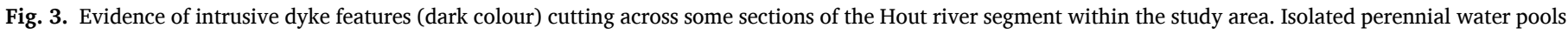

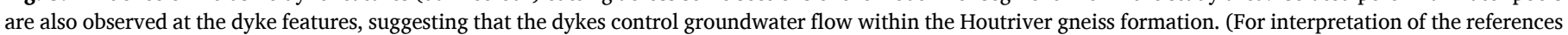
to colour in this figure legend, the reader is referred to the Web version of this article.)

orthoclase and quartz with minor plagioclase, biotite and hornblende (Du Toit, 2001; Holland, 2011). The Hout River gneiss characterising the catchment weathers into typical sandy soil that covers the greater area of the catchment. The identified aquifer within the catchment is known as the Houdenbrak aquifer and falls within the government monitoring programme under the Water Act 1956 (Pietersen et al., 2011). According to investigations carried out by Jolly (1986), the study area consists of two aquifers units; a weathered aquifer and a high yielding fractured rock aquifer unit. The weathered zone of the Houdenbrak aquifer has a variable depth within the range of $15-50 \mathrm{~m}$, and is underlain by fractured bedrock of granitic gneiss whose extent much thicker reaching a depth of about $120 \mathrm{~m}$ (Jolly, 1986). The two zones of the composite aquifer in the catchment experience a hydraulic connectivity such that the upper weathered unit with low permeability and high porosity acts as a reservoir that feeds the lower fractured rock with high permeability and lower porosity, (the upper and lower units of the composite aquifer are characterised by storage coefficients of 0.01 and 0.0025 respectively) (Jolly, 1986). Furthermore, the composite aquifer is said to be confined and partially confined in certain locations (Ebrahim et al., 2019., Pietersen et al., 2011). These previous studies suggest that higher borehole yields are experienced when boreholes are drilled into the lower fractured zone that have a blow yields that can reach up to $40 \mathrm{l} / \mathrm{s}$. This can be attributed to good fracture connectivity and the characteristics of the granites in the area. Transmissivity values from the
Groundwater Resource Information Project (GRIP) database range between $4 \mathrm{~m} 2 / \mathrm{d}$ and $40 \mathrm{~m} 2 /$ within the catchment with consistent values occurring around the Mogwadi area (Holland, 2011). In addition to fracturing of the rock matrix, groundwater dynamics are also influenced by the presence of multiple SW -NE -oriented Diabase dykes and pegmatite lineaments which are also visible in certain sections of the study area (Figs. 2 and 3).

\section{Hydrogeophysical investigations}

Several geophysical methodologies were systematically applied in three selected regions based on the occurrence of dykes and other geological features within the study area (Fig. 4). An understanding of each of the utilised methodologies is described in Telford et al. (1990).

The order of application for the geophysical methods (Fig. 5) was 1D ground magnetics using a proton magnetometer followed by frequency domain electromagnetic exploration methods using an EM34 unit as horizontal profiling methods to identify points of potential interest along the line. Finally, Vertical Electrical Sounding (VES) was done on selected potential sites in order to infer the variation and thickness of the underlying layers at selected anomalous regions. In the VES procedure, apparent resistivity is computed by passing electric current (in milliamperes) into the ground through two electrodes and measured potential drop resulting from the resistance offered by the ground by two 


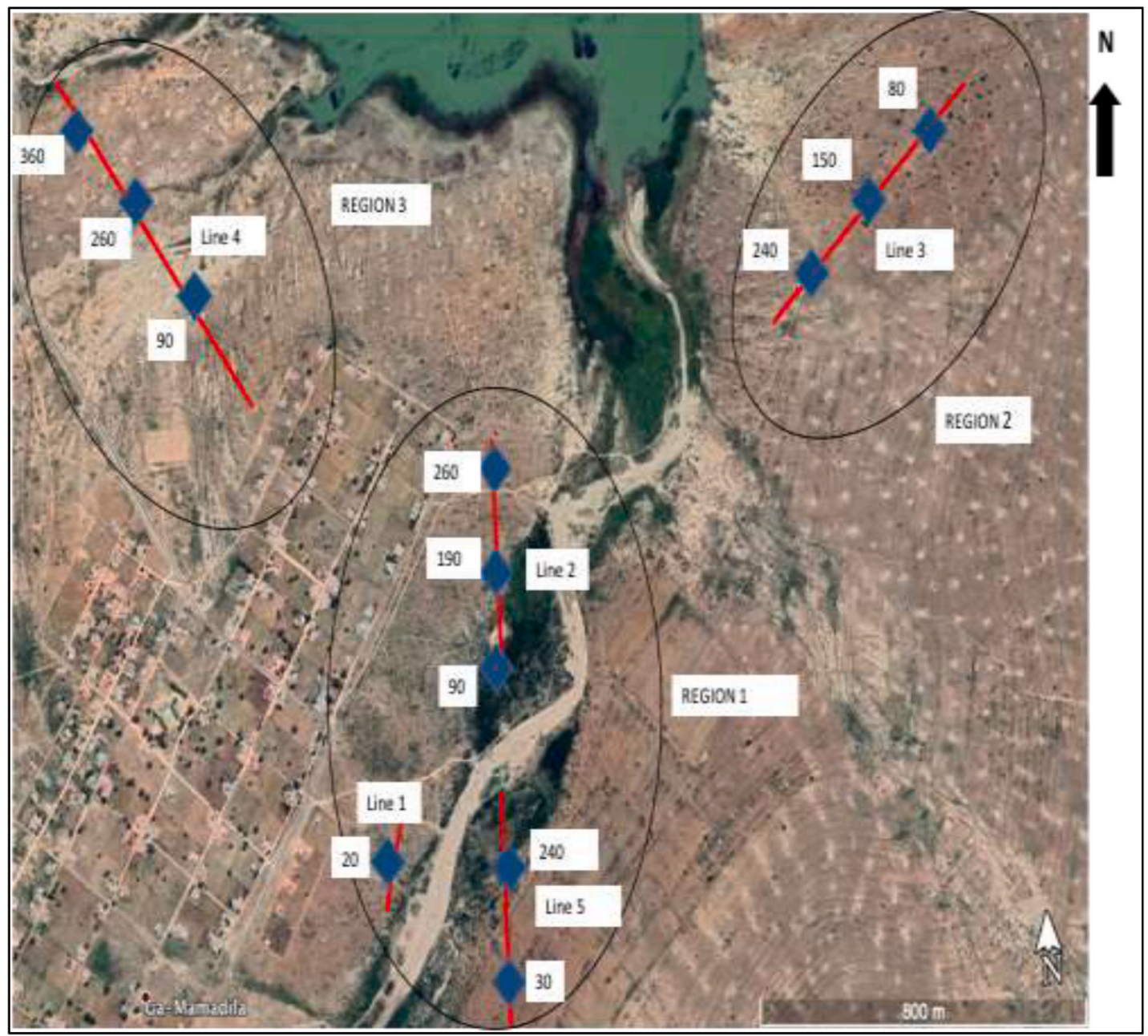

Fig. 4. Google earth images of the Study area showing the horizontal profile lines and positions for vertical electrical sounding sites (in m) for survey regions 1-3.

other potential electrodes placed co-linearly and symmetrically about the center of the electrode arrangement. The field procedure for the VES was carried out using the Wenner -alpha (with $\mathrm{a}=10 \mathrm{~m}$ ) electrode configuration. In this electrode array survey, the distance between the current electrodes is always equal to three times of the potential electrodes with all the electrodes being after each measurement (Wenner, 1916). The choice of the Wenner array was informed by its ability to resolve a multiple layered system because of its high vertical resolution) suitable for a multilayered formation (like the Houtriver gneiss formation described in (Jolly, 1986; Wenner, 1916; Zohdy et al., 1974)). Relatively small current values are sufficient to produce measurable potential differences using the Wenner array (Keller and Frischknecht (1966)).

One dimensional (1D) magnetic profiling was used to assess the presence of potential lateral heterogeneities that could be indicative of groundwater controlling geologic features like the presence of faults, lineaments and dykes that form aquifer boundaries or act as controls to subsurface flow in crystalline basement aquifers (results presented collectively in the following section). The presence of fractures and dykes (which often control groundwater occurrence in crystalline aquifers) resulted in anomalous magnetic signatures in the measured magnetic susceptibilities, thereby making the geomagnetic exploration method a useful tool in groundwater potential evaluation. The magnetic profile lines were such that the lines were perpendicular to the regional trends in the geological strike of dykes and lineaments since they are easily intercepted when a survey is traversing perpendicularly. Data was collected at $10 \mathrm{~m}$ intervals within each line in all the three regions. Total magnetic horizontal profiling plots were used to identify points with contrasting magnetic susceptibilities.

Frequency Domain Electro-Magnetic (FDEM) method was used as a complementary horizontal profiling tool along with the magnetic method in order to come up with an improved selection of the Vertical Electrical Sounding (VES) points along all transect lines. FDEM methods are widely used in groundwater investigations such as inferring preferential groundwater pathways, mapping fracture zones, dykes and faults (Muchingami et al., 2019). The FDEM method is sensitive to contrasts in electrical conductivity of the subsurface and involves the propagation of time-varying low-frequency ( $\sim 100 \mathrm{~Hz}$ to $1 \mathrm{MHz}$ ) electromagnetic fields in and over the earth (Telford et al., 1990). The conductivity of geologic materials is highly dependent upon the water content and the concentration of dissolved minerals (electrolytes). 


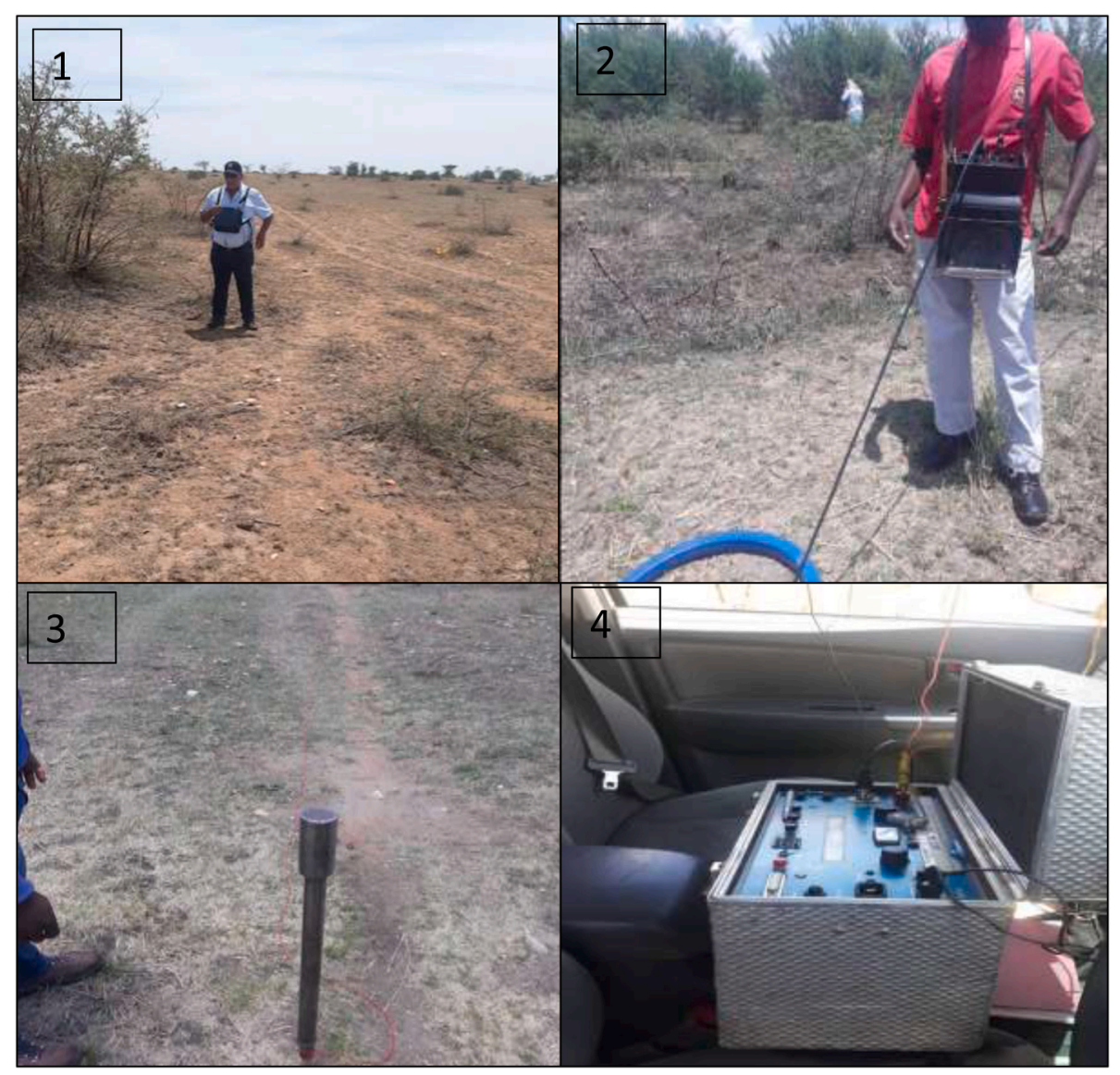

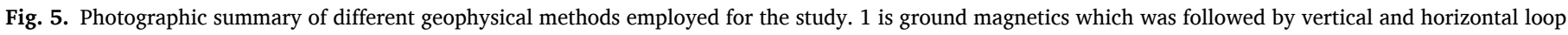

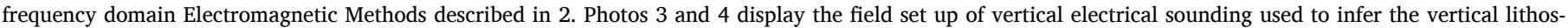
tratigraphic variations within the study.

After the magnetic and electromagnetic profiling, the vertical electrical sounding (VES) was applied to specially selected sites in order to investigate the lithostratigraphic variations of the subsurface using the Schlumberger electrode arrangement. In the VES form, a series of apparent resistivity values are acquired at successively greater electrode spacing while maintaining a fixed central reference point (The greater the electrode spacing the deeper the layers through which the induced current passes, hence greater depth of investigation, (Chandra et al., 2010; Zohdy et al., 1974; Breusse, 1963). The method utilised direct currents to investigate the electrical properties (electrical resistivity) of the subsurface and is based on the principle of existence of electrical resistivity contrasts between different earth materials in accordance to rock matrix, moisture, fluid saturation salinity and porosity factors (Telford et al., 1990). In a crystalline basement formation, reduced electrical resistivity values are often indicative of a potentially groundwater bearing region (e.g. in Muchingami et al., 2019). The measured apparent electrical resistivity, which is determined from the measured potential difference, injected current and the electrode configuration is indicative of the electrical properties of subsurface material present within the medium with groundwater bearing formations in crystalline aquifers being more conductive of electricity, (hence low apparent electrical resistivity values).

\section{Results and interpretation}

The interpretation of results from the field investigation was based on plots of both profiling (magnetic and EM) and VES field measurements (Figs.6-11). For each profile line in the respective regions, results of the lateral profiling using magnetic and electromagnetic methods were used to identify the anomalous sites (indicative of geological contacts or structures likely to control groundwater occurrence) are first presented. Anomalous zones from which the electrical resistivity sounding was then done to infer the probable depth layering and the possible distribution of various litho-stratigraphic sections that could influence the groundwater potential of the area are also indicated by arrows showing the respective position of the anomaly. The interpretation was done according to region 1, 2 and 3 (Fig. 4) and was done through analysing the degree of consistency presented by the plots from Magnetic, horizontal FDEM and vertical FDEM profiles.

Region 1 had three profile lines which were carried out during the field surveys, profile 1 and 2 respectively. 1D magnetics survey and both the horizontal and vertical electromagnetics done on profile line 1 (Fig. 6a) in order to investigate the variations in horizontal geologic structures that likely influence groundwater dynamics within the study area. The two profiling methods managed to pick an anomalous region at the $20 \mathrm{~m}$ mark point along the line (Fig. 6). A magnetic anomaly 


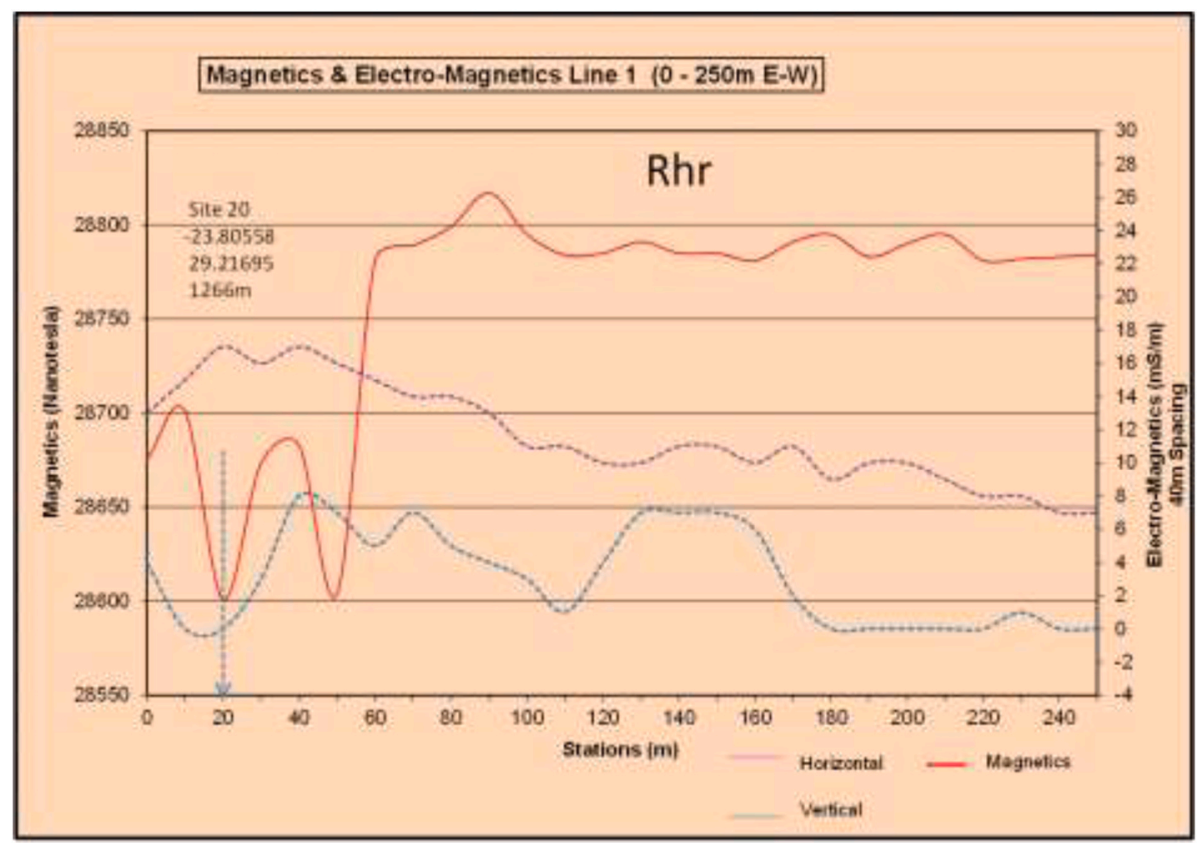

[a]

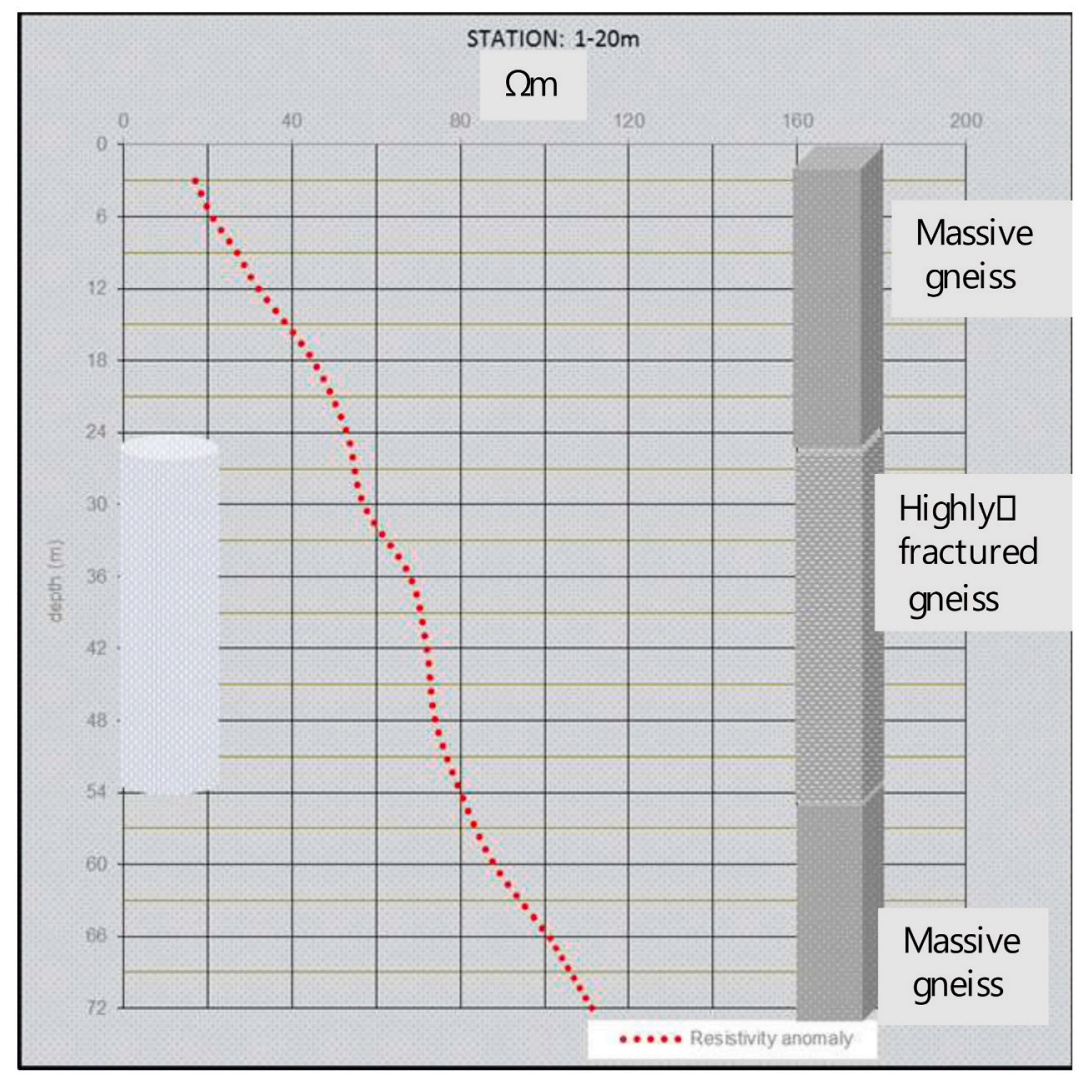

(b)

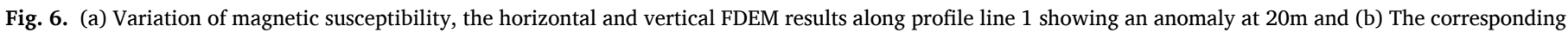
vertical electrical resistivity section together with the inferred depth variation profile from the interpretation of field electrical resistivity results. 


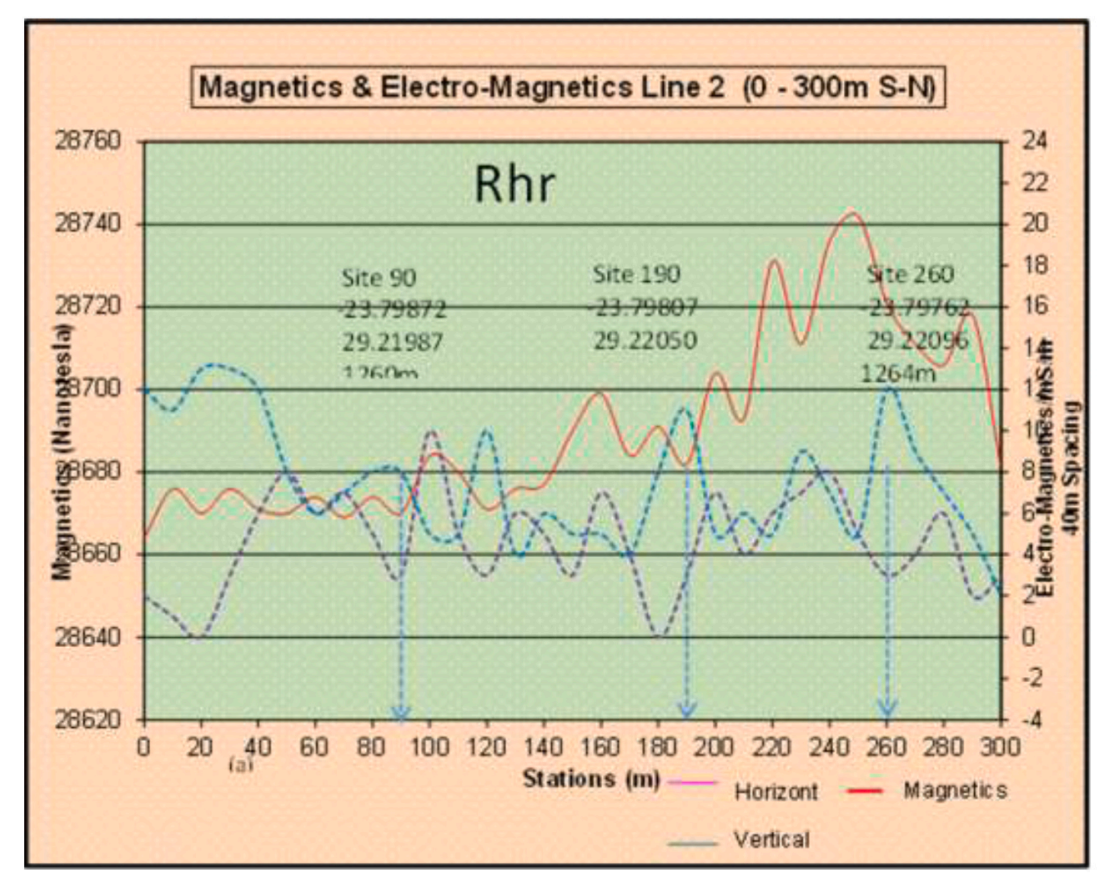

(a)

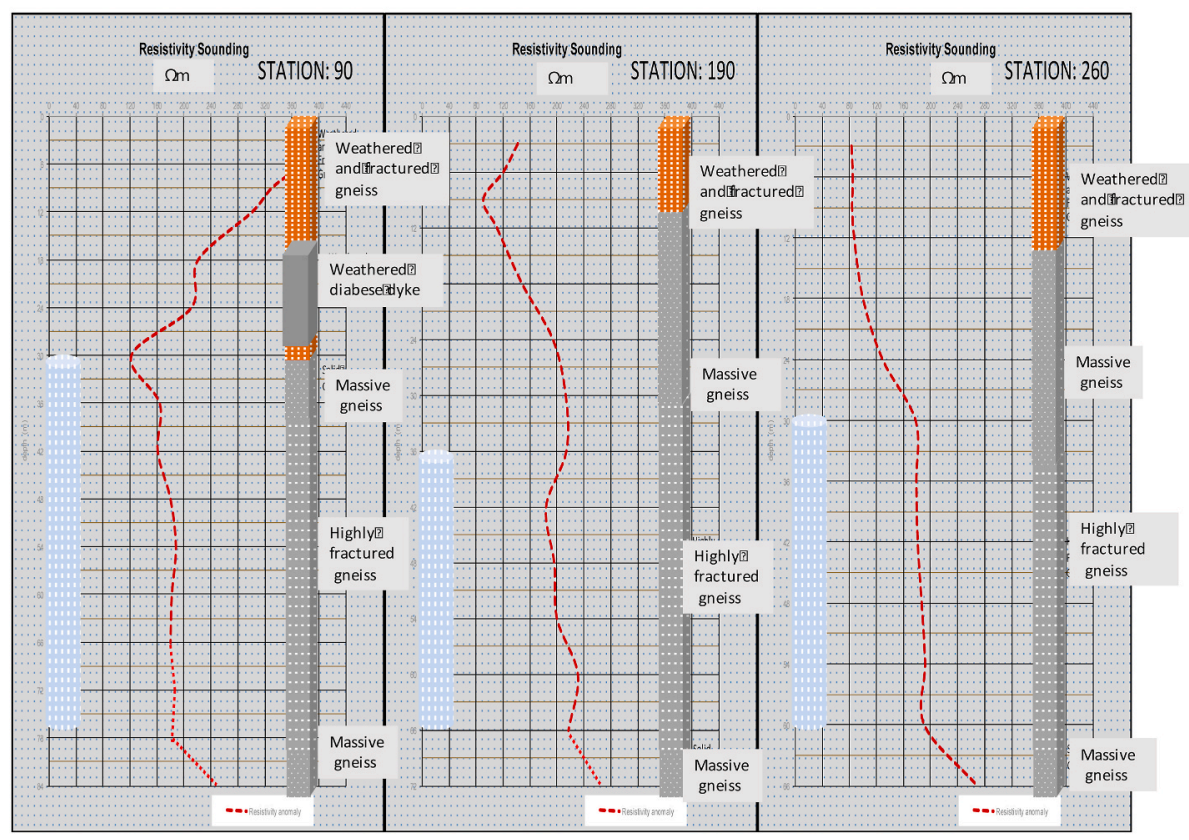

(b)

Fig. 7. (a) Variation of magnetic susceptibility, the horizontal and vertical FDEM results along profile line 2 showing potential groundwater anomalies at $90 \mathrm{~m}$, $190 \mathrm{~m}$ and $260 \mathrm{~m}$ and (b) The corresponding vertical electrical resistivity sections together with the inferred depth variation profile from the interpretation of field electrical resistivity results. 


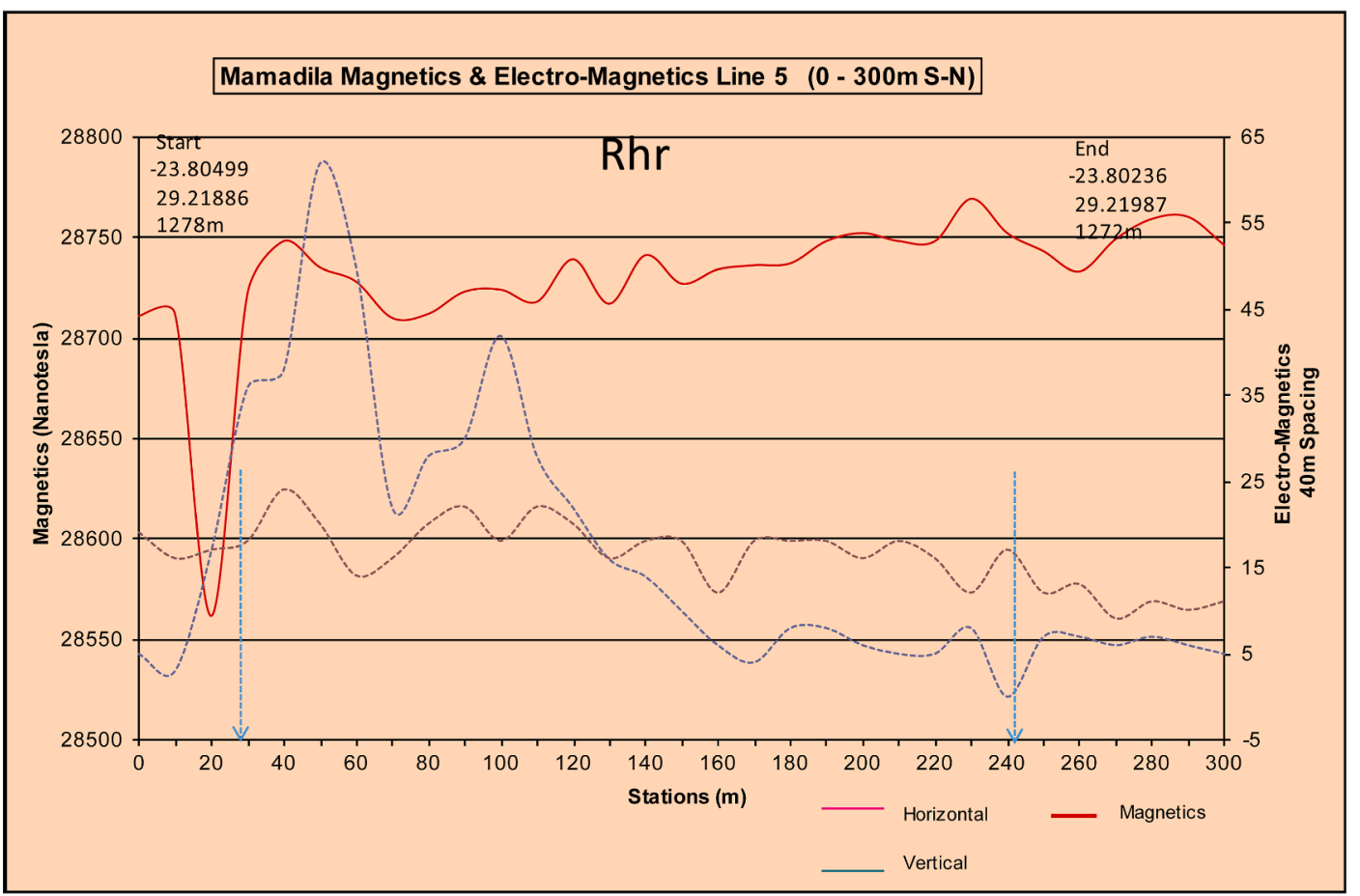

(a)
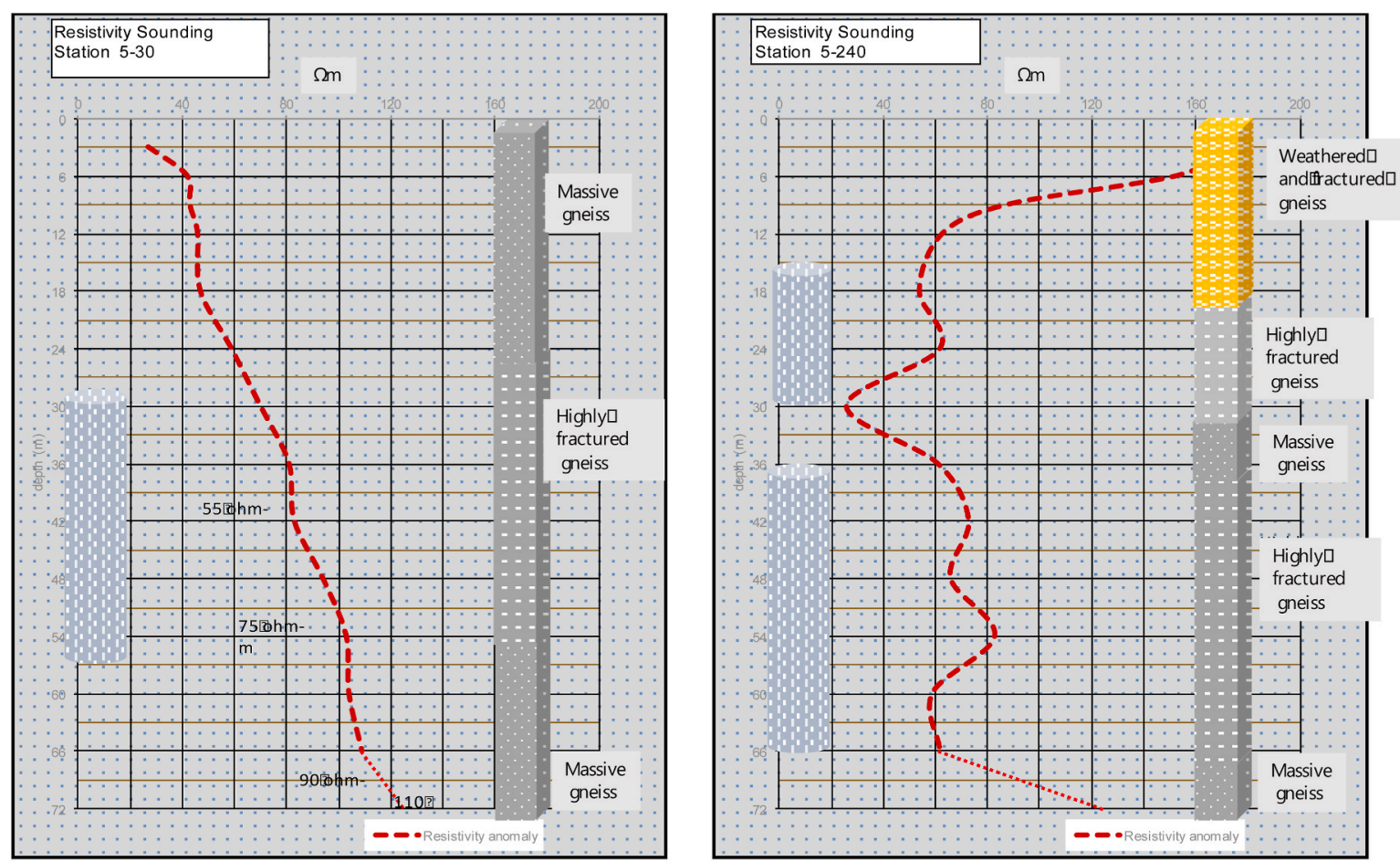

(b)

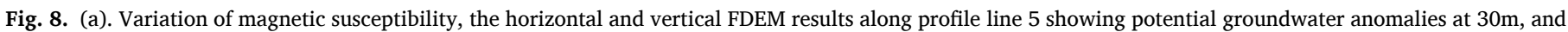

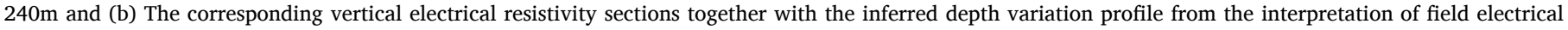
resistivity results. 
(a)

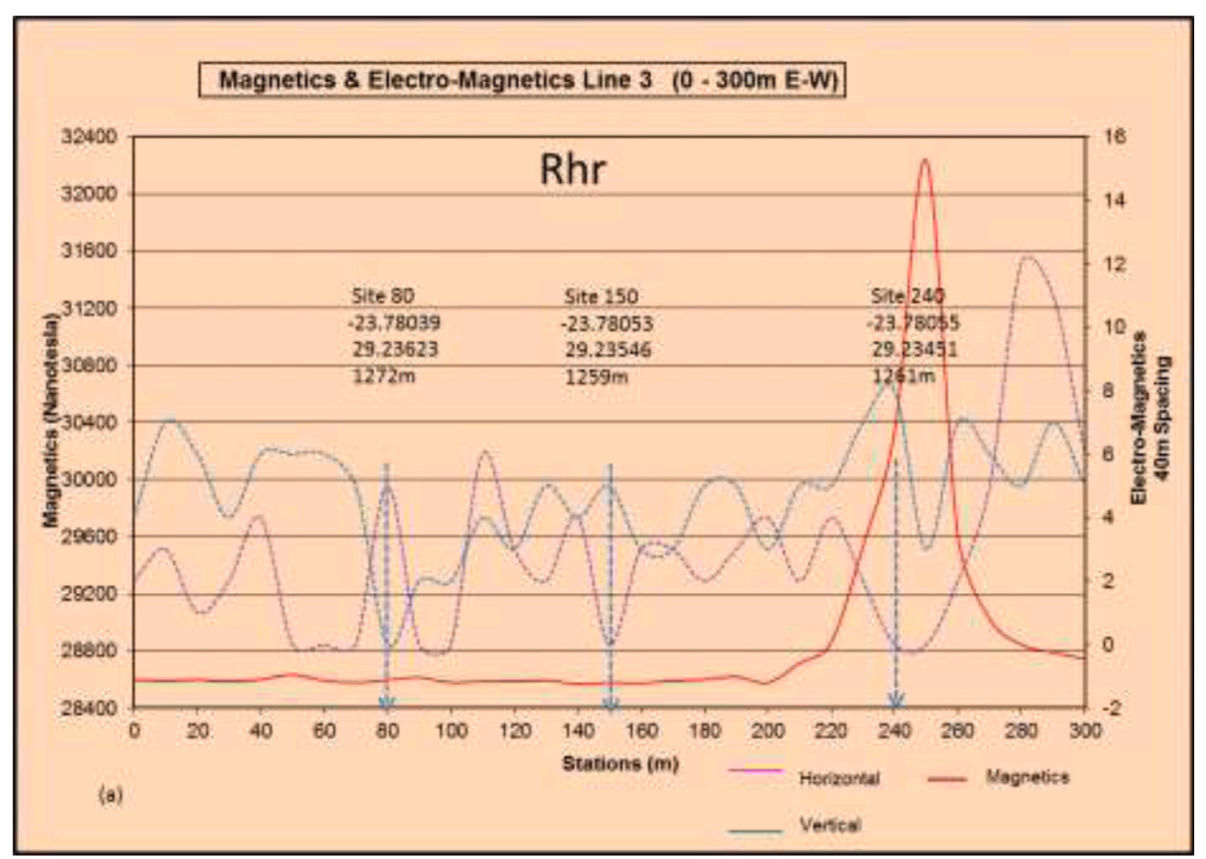

(b)

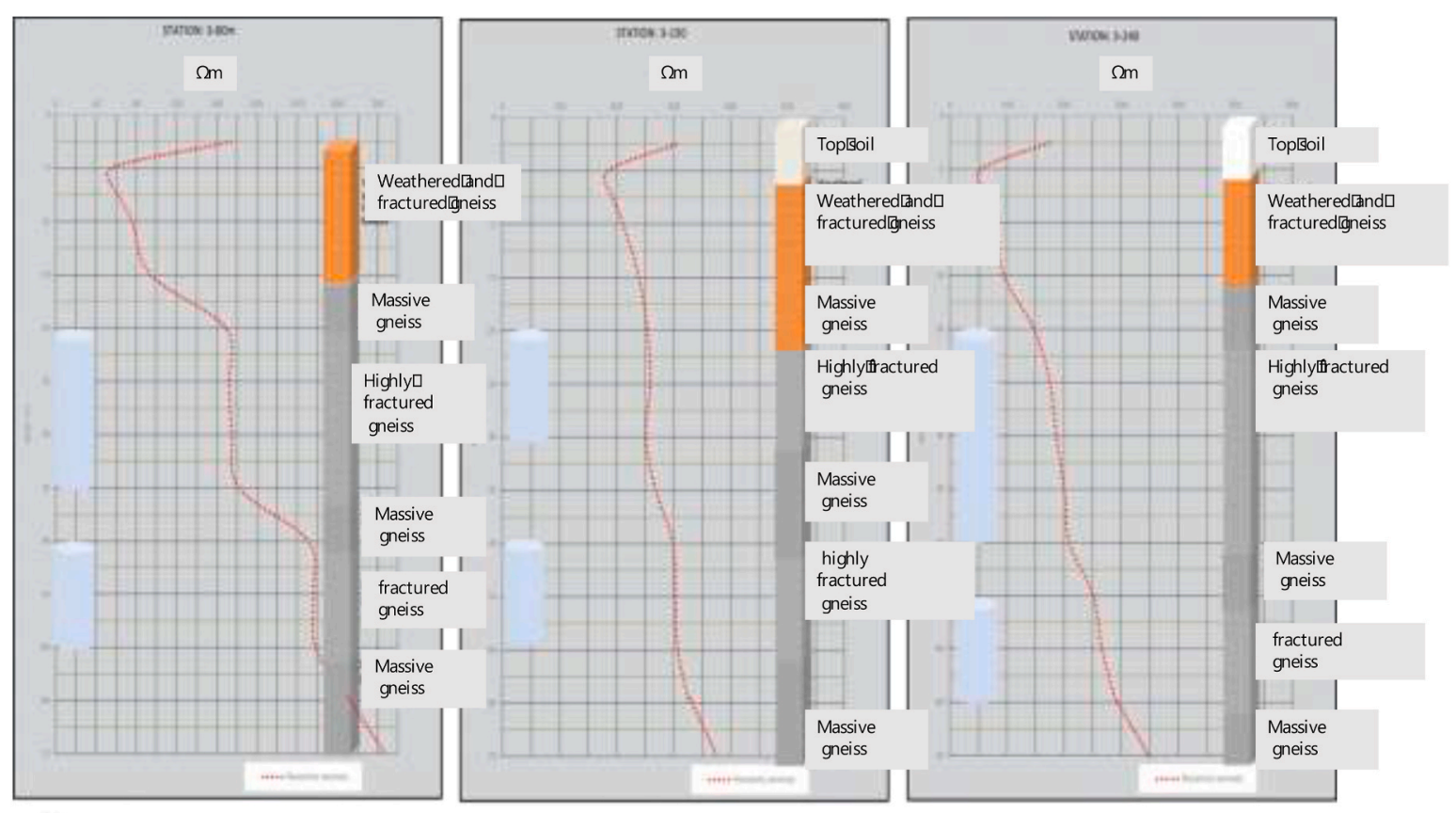

(b)

Fig. 9. (a) Variation of magnetic susceptibility, the horizontal and vertical FDEM results along profile line 3 showing potential groundwater anomalies at $80 \mathrm{~m}, 150 \mathrm{~m}$ and $240 \mathrm{~m}$ and (b) The corresponding vertical electrical resistivity sections together with the inferred depth variation profile from the interpretation of field electrical resistivity results. 


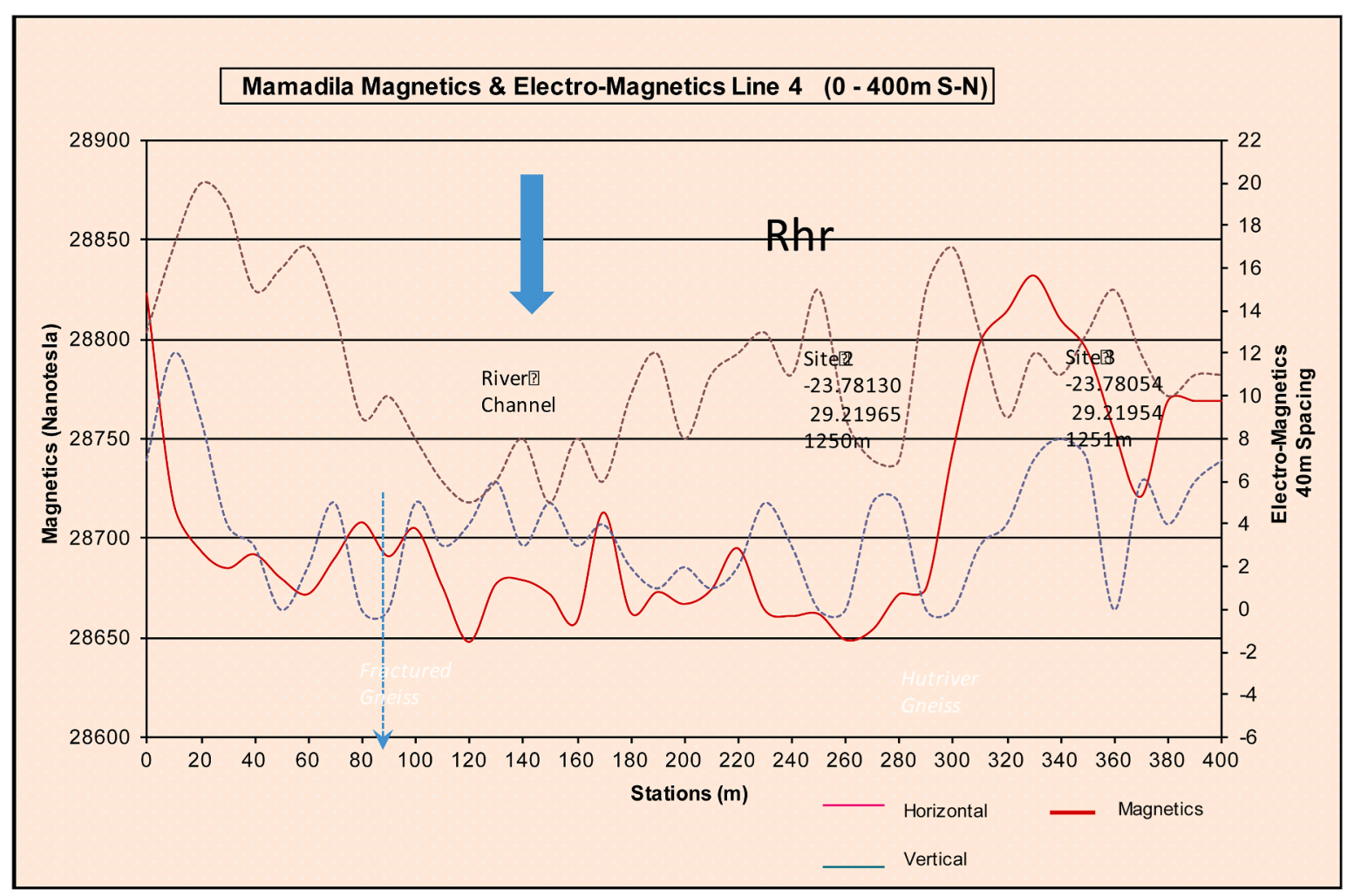

(a)

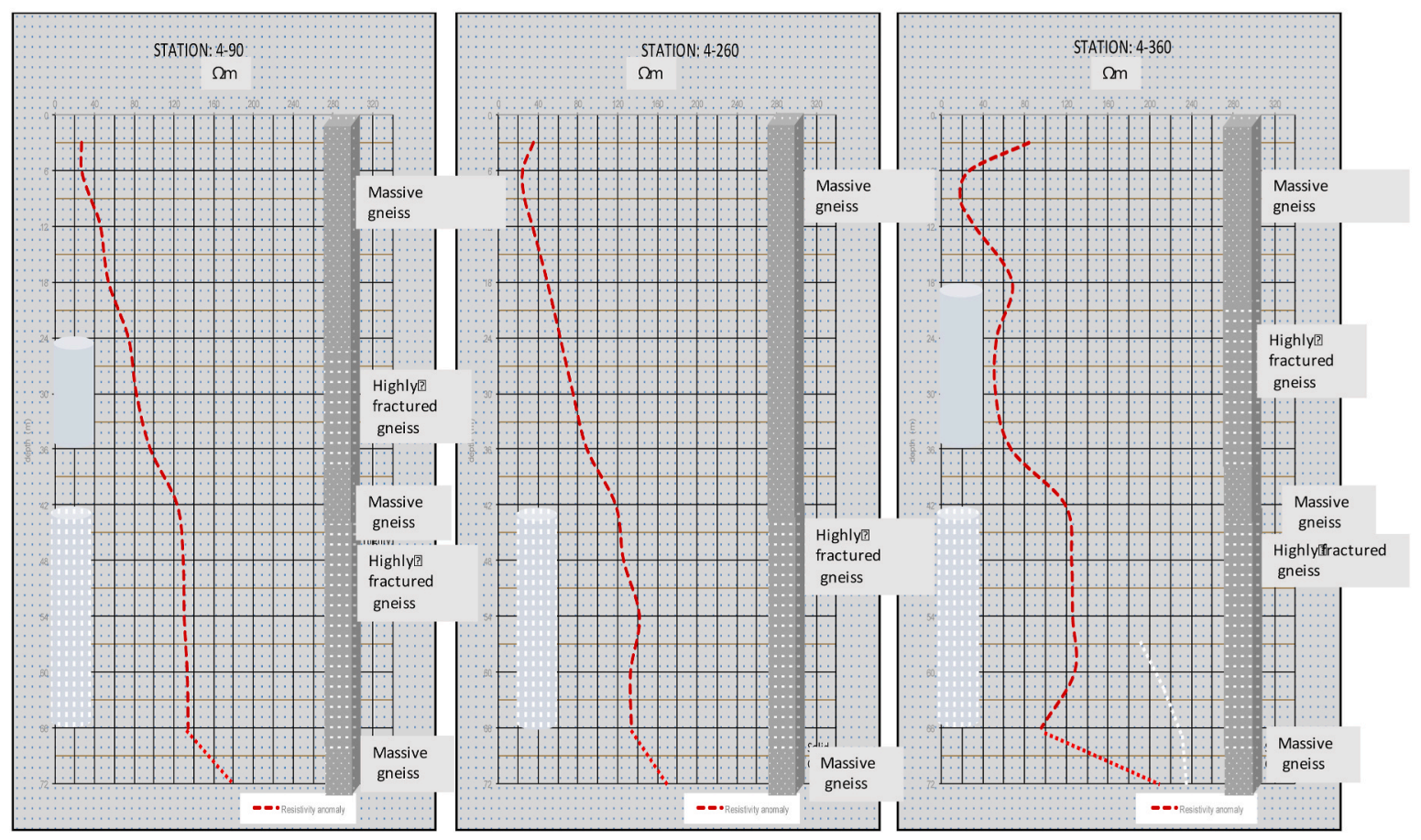

(b)

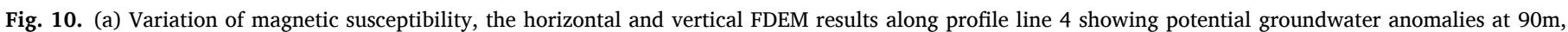

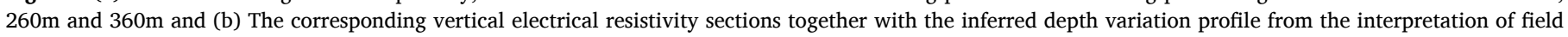
electrical resistivity results. Correlation of geophysical results with drilling logs. 


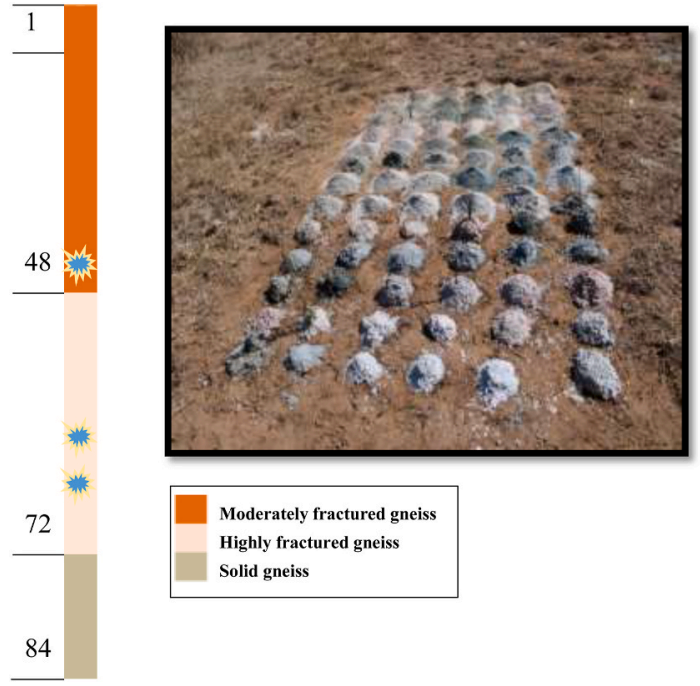

Fig. 11. Borehole drill log profile and sample images for borehole a test borehole within the study area.

Table 1

Information summary of boreholes drilled at the study area.

\begin{tabular}{|c|c|c|c|}
\hline Number & $\begin{array}{l}\text { depth/ } \\
\text { m }\end{array}$ & $\begin{array}{l}\text { blow } \\
\text { yield }(1 / s)\end{array}$ & Summary \\
\hline HO43126 & 84 & 5 & $\begin{array}{l}\text { Cutting across different bands of solid Hout } \\
\text { River gneiss and highly weathered and } \\
\text { potentially water bearing weathered } \\
\text { pegmatite lineament }\end{array}$ \\
\hline HO43127 & 120 & 5.6 & $\begin{array}{l}\text { Cutting through a highly fractured pegmatite } \\
\text { layers and weathered Diabase dyke }\end{array}$ \\
\hline HO43128 & 48 & 8.4 & $\begin{array}{l}\text { Cutting through highly fractured pegmatite } \\
\text { layers and at the edge of a Diabase dyke }\end{array}$ \\
\hline
\end{tabular}

detected at $50 \mathrm{~m}$ is also indicative of a potential geological contact. However, this magnetic anomaly is not well complemented with significant changes in electrical conductivity from both vertical and horizontal FDEM results, hence the contact at $50 \mathrm{~m}$ may be inferred as a dry geological contact. As such the potential groundwater bearing anomaly at $20 \mathrm{~m}$ was the only one with conditions suitable for further investigations for depth variation using the electrical resistivity sounding method. An inference of the potential lithostratigraphic distribution based on the field electrical resistivity measurements suggested a single fractured region between depth $24 \mathrm{~m}-54 \mathrm{~m}$ from the ground surface (Fig. 6b). Profile line 2 which are part of region 1 , had three main anomalous zones identified using the magnetic profiling and electromagnetic methods (both horizontal and vertical) (Fig. 7a), and VES profiling was done at $90 \mathrm{~m}, 190 \mathrm{~m}$ and $260 \mathrm{~m}$ (Fig. $7 \mathrm{~b}$ ). An additional profile (line 5) was done on the southern side of the riverbank to infer potential groundwater targets. Magnetic and EM profiling showed the existence of anomalous zones at $30 \mathrm{~m}$ and $240 \mathrm{~m}$ on the southern river bank (Fig. 8a), with the VES sections are also presented in Fig. 8b.

Region 2 (Fig. 4) had a single profile (line 3) that was done with an orientation towards the East-West direction towards and was cutting through a pegmatitic lineament. The total length of the line was $300 \mathrm{~m}$. Three major anomalous regions were picked at $80 \mathrm{~m}, 150 \mathrm{~m}$ and $240 \mathrm{~m}$ using the magnetics and both horizontal loop and vertical loop electromagnetic methods (Fig. 9a). The cross-sections inferred from the vertical electrical resistivity sounding suggest highly weathered zone and several fractured sections (Fig. 9b). Multiple fractured layers being suggested from the resistivity cross sections suggest a high groundwater potential within the site.

Region 3 comprised of profile line 4 which was done with a total length of $400 \mathrm{~m}$ and a North South orientation (Fig. 4). The magnetics and electromagnetic survey results showed three anomalous regions at $90 \mathrm{~m}, 260 \mathrm{~m}$ and $360 \mathrm{~m}$ (Fig. 10a). These were further investigated using the electrical resistivity sounding for vertical investigation on the variation of weathered and fractured regions. Results suggested a fractured region mainly in the depths from $42 \mathrm{~m}$ to $70 \mathrm{~m}$ with less potential to get any groundwater strikes before this region, except on the $360 \mathrm{~m}$ mark which has two fractured sections $(18 \mathrm{~m}-36 \mathrm{~m}$ and $40 \mathrm{~m}-60 \mathrm{~m})$ that are inferred from the results (Fig. 10b).

A correlation of drill logs with the geophysical sections was done on some test boreholes that were drilled in line 2 of region 1 and was informed from exploration results. For instance, in one of the test boreholes, HO4-3126, fractured gneiss occurred from the surface to a depth of around $48 \mathrm{~m}$, this is then followed by a highly fractured pegmatite layer that extends for $24 \mathrm{~m}$ before it changes to solid gneiss. Three water strikes were observed during drilling: $49 \mathrm{~m}, 65 \mathrm{~m}$ and $69 \mathrm{~m}$ which generally agrees with the inference from geophysical section Line 2 station 260 (Fig. 11). The borehole drill summary presented in Table 1 and developed lithological section for cross section confirms the complexity that is associated with the typical Houtriver gneiss formation as had been inferred from the geophysical profiling, which had predicted the groundwater occurrence as being controlled by many structures inclusive of diabase dykes, pegmatite lineaments and varying degrees in weathering and fracturing in different sections of the parent gneiss (Fig. 12). The average borehole yield for the boreholes is way greater than the average yield in most crystalline basement aquifers reported in Southern African basement aquifers of 0.1-1 1/s reported in Macdonald et al., (2005). This therefore confirms that the borehole siting procedures were successfully enhanced by the integrated geophysical and geological approach adopted for in the study.

\section{Discussion}

The study results have shown that hydrogeophysical investigations and geological mapping have shown to be useful tools in the identification of drill targets for areas underlain by the geologically complex Houtriver gneiss crystalline basement formation. This was enhanced by the fact that groundwater storage and dynamics within such metamorphic crystalline formation is controlled is mainly influenced by the extend of zone of weathering and existence the fractures and fissures in the fresh rock, creating a high heterogeneity in the formation in terms of lineament distribution and fracture system. The results from magnetic and electromagnetic investigations suggested that there are drastic lateral variations in the aquifer. Such lateral heterogeneities are interpreted to be influenced by existence of structures such as lineaments, dykes and fault zones, which ultimately control groundwater dynamics within the formation. As such they could be sufficiently used to identify anomalous points for potential drill targets that were to be further investigated using VES. The VES results presented from the study results also suggests that groundwater occurrence within such metamorphosed systems is controlled by existence of secondary porosity like joints, fractures as suggested in Taylor (1999), resulting in vertical heterogeneities with alternate wet and dry zones within the formation. Because of such contrast between the groundwater being and dry sections, it was relatively easier to infer sections of localized occurrence of groundwater in the Houtriver gneiss hard-rock formation using electrical resistivity geophysical owing to the lower resistivities of these water-rich zones compared with typical high resistivities of crystalline rocks. The inferred the depth of influence and vertical stratigraphy of the formation from the VES suggested potential groundwater bearing regolith to have resistivity values to be less than $120 \Omega \mathrm{m}$. These values are within the range of that reported in Owen et al. (2005) for groundwater bearing regolith (20-100 $\Omega$-m) for typical basement aquifers in Zimbabwe. Solid bedrock is characterised by high resistivities (often greater than $400 \Omega \mathrm{m}$ in this study) compared to the weathered and fracturing bearing formations (mostly in the $40-120 \Omega \mathrm{m}$ range). A relatively unweathered zone is inferred to be starting from approximately $30 \mathrm{~m}$ below ground surface 


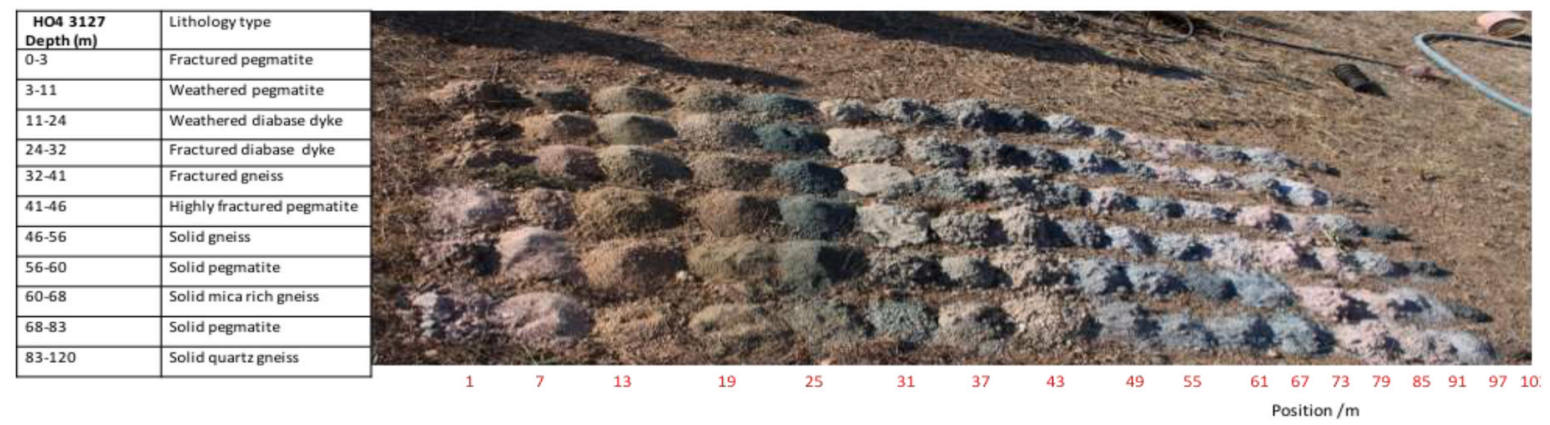

(a)

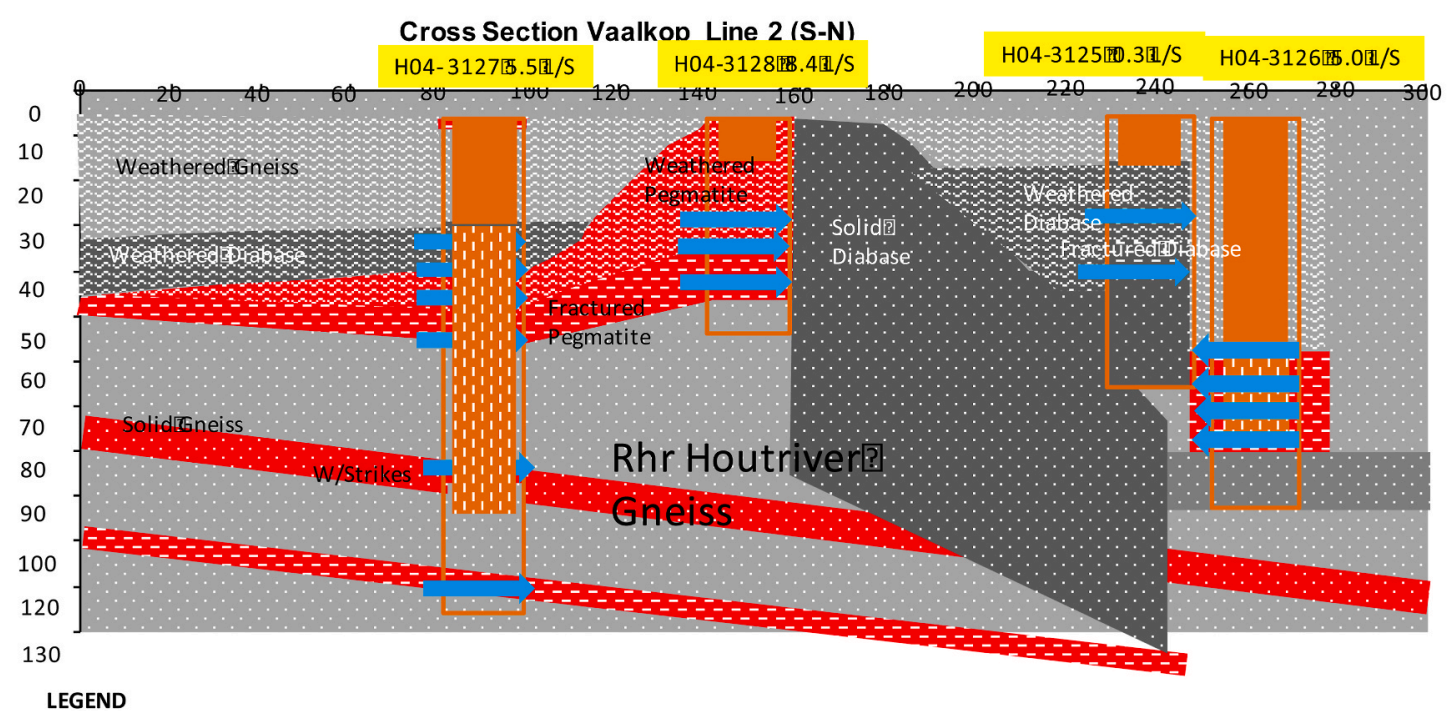

Weathered $\mathbb{G}$ Gneiss

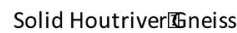

Fractured Pegmatite

Diabase Dyke
Boreholexonstruction

Solidrosing

Perforated国 asing

(b)

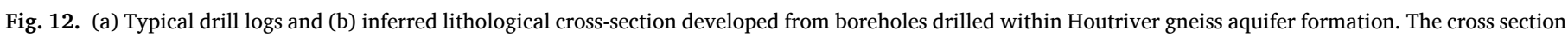
was developed from test boreholes drilled within the study area under the ESGUSA project framework. The blue arrows indicate zones of water strikes.

and is characterised by a resistivity values in excess of $300 \Omega$-m, (marking the end of the regolith zone) and characterised by sections of reduced resistivity values which are inferred as fractured zones (and potential groundwater strikes) occurring within the solid bedrock. Thus, the VES results suggested a multi-layered aquifer formation with fracturing controlling the deeper groundwater bearing sections of the crystalline basement formation. This distinct difference in resistivity within the formation in the profiles was attributed to elevated water content of crystalline rocks which are mainly controlled by the level of weathering in the regolith and fracturing at deeper sections within the study area. Lithological cross section constructed from drill logs samples collected during the test boreholes) confirms the heterogeneity and layering within the formation as was inferred from the hydrogeophysical results. The lithostratigraphic section confirms the complexity that is associated with the Houtriver gneiss aquifer formation whose groundwater occurrence is controlled by many structures inclusive of dipping diabase dykes, pegmatite lineaments and varying degrees in weathering and fracturing. As such the results of the study confirms that the integration of both geological methods and hydrogeophysical methods can be used as sufficient groundwater exploration approach within the Houtriver gneiss formation.

\section{Conclusions and recommendations}

The integration of geophysical and geological investigations was successfully applied in inferring potential drill targets within the 
Houtriver gneiss crystalline basement aquifer system. Due to high heterogeneity in the crystalline basement formation, the aquifer characteristics varied from one place to another in terms of lateral and vertical distribution and hence groundwater availability was variable within the study area. The constructed geo-resistivity pseudo-sections suggested that groundwater occurrence within this formation is described by a heterogeneous multiple-layered units ranging from a depth of 30 - over $72 \mathrm{~m}$ in most cases. Ten potential drill sites were identified from which three test boreholes were drilled and a lithostratigraphic conceptual model developed. The results for the lithostratigraphic model were successfully used to validate the results through from the correlation of the geophysical results with drill logs. The results from the study managed to successfully map out the sections with high weathered zone and fractured regions that are indicative of high groundwater bearing potential. The approach used herein can this be used for technical groundwater resource management within Houtriver gneiss formation.

\section{Author statement}

The authors are grateful to all comments raised by the reviewers.

We have made all effort to address the necessary concerns and improve the quality of our diagrams.

Please find attached response to reviewers 4 concerns for the consideration. We very much hope that the revised manuscript is accepted for publication in the Journal. The response to reviewer $1 \mathrm{~s}$ comments are done on the review comment bullets on the reviewed word document that they attached and sent to us. We really appreciate their effort.

\section{Declaration of competing interest}

The authors declare that they have no known competing financial interests or personal relationships that could have appeared to influence the work reported in this paper.

\section{Acknowledgements}

The Authors would like to appreciate and thank the sterling work done by the the support provided by the Danish Development Center through providing financial support of the project Enhancing Sustainable Groundwater Use in South Africa (ESGUSA), from which this work was part of. Further to this the authors also acknowledge Department of Water and Sanitation (Polokwane) 's resource assessment team for equipment and manpower assistance provided during field work.

\section{Appendix A. Supplementary data}

Supplementary data to this article can be found online at https://doi. org/10.1016/j.pce.2021.103009.

\section{References}

Acworth, R.I., 1987. The development of crystalline basement aquifer in a tropical environment. Q. J. Eng. Geol. 20, 265-272.

Adams, S., 2009. Basement aquifers of southern Africa: overview and research needs. In: Titus, R., Beekman, H., Adams, S., Strachan, L. (Eds.), The Basement Aquifers of South Africa. WRC Report No. TT 428/09. Water Research Commission, Pretoria, p. Pp1-4, 2009.

Breusse, J.J., 1963. Modern Geophysical Methods for Surface Water Exploration. Geophysics 28, 638-657.
Chandra, S., Dewandel, B., Dutta, S., Ahmed, S., 2010. Geophysical model of geological discontinuities in a granitic aquifer: analyzing small scale variability of electrical resistivity for groundwater occurrences. J. Appl. Geophys. 71, 137-148.

Chilton, P.J., Foster, S.S.D., 1995. Hydrogeological characterization and water-supply potential of basement aquifers in tropical Africa. Hydrogeol. J. 3 (1), 36-49.

Chilton, P.J., Smith-Carington, A.K., 1984. Characteristics of the Weathered Basement Aquifer in Malawi in Relation to Rural Water Supplies. Challenges in African Hydrology and Water Resources, Proc. Harare Symposium, pp. 57-72. July 1984.

Chuma, C., Hlatywayo, D.J., Zuu, J., Muchingami, I., Mashingaidze, R.T., Midzi, V., 2013. Modelling the subsurface geology and groundwater occurrence of the Matsheumhlope low yielding aquifer in Bulawayo urban, Zimbabwe. J. Geogr. Geol. 5 (3), 158-175.

Davis, S.N., Turk, L.J., 1964. Optimum depth of well in crystalline rocks. Ground Water $2,6-11$.

Du Toit, W.H., 2001. The Influence of Granite Intrusions on the Host Rock in Terms of Occurrence in Groundwater in the Pietersburg Area. M.Tech. (Geology) Thesis. Technicon, Pretoria, South Africa.

du Toit, W., 2001. An investigation into the occurrence of groundwater in the contact aureole of large granite intrusions (batholiths) located west and northwest of Pietersburg. Dept. of Water Aff. For., Pretoria, South Afr. 1.

Ebrahim, G.Y., Villholth, K.G., Boulos, M., 2019. Integrated hydrogeological modelling of hard-rock semi-arid terrain: supporting sustainable agricultural groundwater use in Hout catchment, Limpopo Province, South Africa. Hydrogeol. J. 27, 965-981.

Eswaran, H., Bin, W.C., 1978. A study of deep weathering profile on granite in peninsular Malaysia: I. Physico-chemical and micromorphological properties. J. Soil Sci. Soc. Am. 42, 144-149.

Holland, M., Witthüser, K.T., 2011. Evaluation of geologic and geomorphologic influences on borehole productivity in crystalline bedrock aquifers of Limpopo Province, South Africa. Hydrogeol. J. 19, 1065-1083.

Jolly, J., 1986. Report No. GH 3495. In: Borehole/Irrigation Survey and Groundwater Evaluation of the Doringlaagte Drainage Basin. DWAF, Pretoria.

Keller, G.V., Frischknecht, F.C., 1966. Electrical Methods in Geophysical Prospecting. Pergamon Press, Oxford.

Ledger, E.B., Rowe, M.W., 1980. Release of uranium from granitic rocks during in situ weathering and initial erosion (central Texas). Chem. Geol. 29, 227-248.

MacDonald, A., Davies, J., Calow, R., Chilton, J., 2005. Developing Groundwater: a Guide for Rural Water Supply. ITDG Publishing, Rugby, UK.

Martinelli, E., Hubert, G.L., 1985. A report to the ministry of energy and water resources and development. Master plan for rural water supply and sanitation. Norad. Hydrogeology 2, 109-118.

Metwaly, M., El-Qady, G., Massoud, U., El-Kenawy, A., Matsushima, J., Al-Arifi, N., 2009. Integrated geoelectrical survey for groundwater and shallow subsurface evaluation: case study at Siliyin spring, El-Fayoum, Egypt. Int. J. Earth Sci. 99, $1427-1436$.

Muchingami, I., Chuma, C., Hlatywayo, D.J., Gumbo, M., Mashingaidze, R.T., 2019. Review; Approaches to groundwater exploration and resource evaluation in crystalline basement aquifers of Zimbabwe. IAH Hydrogeol. J. 27, 915-928.

Nahon, D.B., 1991. Introduction to the Petrology of Soils and Chemical Weathering. Wiley.

Owen, R.J., Gwavava, O., Gwaze, P., 2005. Multi- electrode resistivity survey for groundwater exploration in the Harare greenstone belt, Zimbabwe. Hydrogeol. J. 14, 244-252.

Pickens, J.F., Grisak, G.E., Avis, J.D., Belanger, D.W., Thury, M., 1987. Analysis and interpretation of borehole hydraulic tests in deep boreholes; principles model development, and applications. Water Resour. Res. 23 (7), 1341-1375.

Pietersen, K., Beekman, H., Holland, M., 2011. South African Groundwater Governance Case Study. WRC Report No. KV 273/11. Water Research Commission, Pretoria.

Robins, N.S., Davies, J., Farr, J., 2013. Groundwater supply and demand from Southern Africa's crystalline basement aquifer - evidence from Malawi. Hydrogeol. J. 21 (4), 905-917.

Tardy, Y., 1971. Characterization of the principal weathering types by the geochemistry of waters from some European and African crystalline massifs. Chem. Geol. 7, 253-271.

Telford, E., Geldart, W.M., Sheriff, R.E., 1990. Applied Geophysics. Cambridge University Press, UK.

Wenner, F., 1916. A method of measuring earth resistivity. Bull. Bureau of Standards 12, 469-478.

Witthüser, K.T., Holland, M., Rossouw, T.G., Rambau, E., Bumby, A.J., Petzer, K.J., Dennis, I., Beekman, H., Van Rooy, J.L., Dippenaar, M., De Wit, M., 2010. Hydrogeology of Basement Aquifers in the Limpopo Province. WRC Report No. 1693/1/10. Water Research Commission, Pretoria.

Wright, E.P., 1992. The hydrogeology of crystalline basement aquifers in Africa. Geol. Soc. London Spec. Publ. 66, 1-27.

Zohdy, A.A.R., 1969. Application of deep electrical soundings for groundwater exploration in Hawaii. Geophysics 34, 584-600.

Zohdy, A.A.R., Eaton, G.P., Mabey, D.R., 1974. Application of surface geophysics to Ground-water investigations: techniques of Water-resources. Invest. U.S. Geol. Surv. Book 2, Chapter D1, 116. 